\title{
PENGARUH PEMBERIAN BEBERAPA PESTISIDA NABATI UNTUK MENGENDALIKAN JAMUR TULAR BENIH KACANG TANAH (Arachis hypogeae L.) DAN PENGARUHNYA TERHADAP DAYA KECAMBAH BENIH
}

\section{The Impact of Applying Organic Pesticide to Control Seed-Borne Fungi on Peanut Seeds (Arachis hypogeae L.) and its Effect on Seed Germination}

\author{
Muhammad Ali, Sonia \\ Jurusan Agroteknologi, Fakultas Pertanian, Universitas Riau \\ Email: Soniajoong01@gmail.com/0813-3362-1525 \\ [Diterima: Februari 2021; Disetujui: April 2021]
}

\begin{abstract}
Seedborne diseases on peanut seeds can be controlled by using plant leaf extracts which applied by seed treatment. The plants leaf used, such as: sambiloto leaves extract, bay leaves extract, basil leaves extract and guava leaves extract. The aim of this research is to study the effect of application several plants leaf extract and obtain the best extract to control seedborne fungal pathogens on peanut seeds and its effect to germination of peanut seeds. The research has been conducted at the Laboratory of Plant Disease and Greenhouse Experimental Farm at Faculty of Agriculture, Riau University, Pekanbaru. This research has been conducted experimentally by using a completely randomed design (CRD), consisting of 5 treatments, namely: without application of plants leaf extract $\left(\mathrm{E}_{0}\right)$, sambiloto leaves extract $30 \%\left(\mathrm{E}_{1}\right)$, bay leaves extract $30 \%\left(\mathrm{E}_{2}\right)$, basil leaves extract $30 \%\left(\mathrm{E}_{3}\right)$ and guava leaves extract $30 \%\left(\mathrm{E}_{4}\right)$. The data obtained were statistically analyzed with analysis of variance and to compare the mean of treatments, and Tukey's test at level 5\% was applied. The result obtained 5 isolate seedborne fungus on peanut seeds. The results showed that application of basil leaves extract was able to inhibit the growth of Rhizoctonia sp. (30.25\%), Macrophomina sp. (41,00\%), Rhizopus sp. (20,25\%) and Aspergillus sp. (15,00\%), the extract of bay leaves had a higher inhibition of Aspergillus $s p$. (31.25\%). The application of bay leaves extract resulted in a better germination rate of $(93.00 \%)$. The application of the four plants leaf extract were not able to affect the total normal germination seeds and seedling height.
\end{abstract}

Keywords: Peanut Seeds, Leaf Extracts, Seedborne Fungi, Germination.

\begin{abstract}
ABSTRAK
Penelitian ini bertujuan untuk menguji dan mendapatkan ekstrak daun tanaman yang terbaik untuk mengendalikan jamur patogen tular benih kacang tanah dan pengaruhnya terhadap daya kecambah benih kacang tanah. Penelitian ini dilaksanakan di Laboratorium Penyakit Tumbuhan dan di Rumah Kasa UPT Kebun Percobaan Fakultas Pertanian Universitas Riau Pekanbaru. Penelitian dilakukan secara eksperimen dengan menggunakan rancangan acak lengkap (RAL) yang terdiri dari 5 perlakuan. Perlakuan yaitu: Tanpa pemberian ekstrak daun tanaman $\left(\mathrm{E}_{0}\right)$, Ekstrak daun Sambiloto 30\% $\left(\mathrm{E}_{1}\right)$, Ekstrak daun salam 30\% ( $\left.\mathrm{E}_{2}\right)$, Ekstrak daun Kemangi 30\% $\left(\mathrm{E}_{3}\right)$ dan Ekstrak daun Jambu biji $30 \%\left(\mathrm{E}_{4}\right)$. Data yang diperoleh dilakukan uji lanjut BNJ (beda nyata jujur) pada taraf $5 \%$. Hasil penelitian menunjukkan bahwa pemberian ekstrak daun kemangi mampu menghambat pertumbuhan Rhizoctonia sp. sebesar 30,25\%, Macrophomina sp. sebesar 41,00\%, Rhizopus sp. sebesar 20,25\% dan Aspergillus sp. sebesar $15,00 \%$, serta ekstrak daun salam memberikan daya hambat lebih tinggi terhadap jamur Aspergillus sp. sebesar 31,25\%. Pemberian ekstrak daun salam menghasilkan daya kecambah lebih baik sebesar 93,00\%. Pemberian keempat ekstrak daun tanaman tidak berpengaruh terhadap jumlah bibit tumbuh normal dan tinggi bibit.
\end{abstract}

Kata kunci: Benih Kacang Tanah, Ekstrak Daun Tanaman, Jamur Tular Benih, Daya Kecambah 


\section{PENDAHULUAN}

Kacang tanah merupakan salah satu tanaman pangan yang bijinya memiliki kandungan gizi yang cukup tinggi, sehingga banyak dikonsumsi oleh masyarakat. Kacang tanah dapat dikonsumsi secara langsung maupun diolah menjadi bahan baku beberapa industry, sehingga kebutuhannya akan terus meningkat seiring meningkatnya jumlah penduduk. Peningkatan kebutuhan kacang tanah tidak selalu diikuti oleh produksinya yang meningkat. Berdasarkan data Badan Pusat Statistik (2019) produktivitas kacang tanah di Provinsi Riau pada tahun 2016 sebesar 9,82 ton.ha ${ }^{-1}$, tahun 2017 sebesar 10,03 ton.ha ${ }^{-1}$ dan pada tahun 2018 mencapai 10,87 ton.ha ${ }^{-1}$ meski mengalami kenaikan dalam tiga tahun terakhir, namun masih rendah jika dibandingkan dengan produktivitas di daerah lainnya pada tahun 2018 seperti Provinsi Jambi mencapai 14,07 ton.ha ${ }^{-1}$, Provinsi Sumatera Barat mencapai 14,04 ton.ha ${ }^{-1}$, Provinsi Sumatera Selatan mencapai 13,61 ton.ha ${ }^{-1}$ dan Provinsi Sumatera Utara mencapai 12,62 ton.ha ${ }^{-1}$.

Rendahnya produktivitas kacang tanah di Provinsi Riau dapat disebabkan oleh mutu benih yang rendah. Rendahnya mutu benih kacang tanah dapat disebabkan oleh infeksi dari jamur terbawa benih seperti Aspergilus flavus, Rhizopus spp., Fusarium oxysporum F.moniliforme, Sclerotium rolfsii, Macrophomina phaseolina, Penicillium sp. dan Rhizoctonia solani (Shazia et al., 2004), yang dapat meningkatkan kematian bibit maupun tanaman, menimbulkan kerugian dalam proses produksi dan dapat, menurunkan hasil serta meningkatkan perkembangan penyakit di lapangan.

Pengendalian jamur patogen tular benih dapat dilakukan dengan melakukan perlakuan benih. Perlakuan benih yang umum digunakan adalah penggunaan fungisida sintetis yang membutuhkan biaya yang relatif tinggi dan dapat mencemari lingkungan serta menimbulkan gangguan kesehatan bagi manusia, sehingga perlu dicari solusi lain, yaitu penggunaan fungisida nabati yang lebih ramah lingkungan.

Tanaman yang dapat digunakan sebagai fungisida nabati yaitu daun sambiloto (Andrographis paniculata Ness.), daun Kemangi (Ocimum basilicum L.), daun Salam
(Syzygium polyanthum) dan daun Jambu Biji (Psidium guajava L.). Masing-masing daun tanaman memiliki kandungan senyawa yang bersifat racun terhadap jamur patogen pada benih.

\section{METODE PENELITIAN}

Penelitian ini telah dilaksanakan di Laboratorium Penyakit Tumbuhan dan di Rumah Kasa UPT Kebun Percobaan Fakultas Pertanian Universitas Riau Kampus Bina Widya, Simpang Baru Panam Pekanbaru. Penelitian dilaksanakan selama 4 bulan dari bulan Mei 2019 sampai Agustus 2019.

Bahan yang digunakan dalam penelitian adalah benih kacang tanah varietas Talam 1 dari Balai Penelitian Tanaman Aneka Kacang dan Umbi (BALITKABI) Malang, daun sambiloto dan kemangi diambil dari Kelurahan Maharatu, Kota Pekanbaru, daun salam diambil dari Kelurahan Umban Sari, Kota Pekanbaru, daun jambu biji diambil dari UPT Fakultas Pertanian Universitas Riau, aquades steril, alkohol 70\%, $\mathrm{NaOCl} 5,25 \%$, Agristick, potato dextrose agar, Amoksilin, aluminium foil, plastic wrap, spritus, plastik transparan, kertas saring, tisu gulung, kertas label dan tanah lapisan atas.

Alat yang digunakan dalam penelitian ini adalah cawan petri berdiameter $9 \mathrm{~cm}$, baki perkecambahan berukuran 40 x $25 \times 10 \mathrm{~cm}$, jarum ose, pinset, pipet tetes, cork borer, gelas piala $1000 \mathrm{ml}$, erlenmeyer $500 \mathrm{ml}$, erlenmeyer $250 \mathrm{ml}$, gelas ukur, batang pengaduk kaca, laminar air flow cabinet, inkubator, mikroskop, kompor gas, lampu bunsen, korek api, handsprayer, gelas objek, gelas penutup, gunting, timbangan analitik, blender, oven, refrigerator, dandang dan kain kassa.

Penelitian dilakukan secara eksperimen dengan menggunakan rancangan acak lengkap (RAL) yang terdiri dari 5 perlakuan dan 4 ulangan sehingga diperoleh 20 unit penelitian. Perlakuan yang diberikan adalah beberapa jenis ekstrak daun tanaman (E) dengan konsentrasi $30 \%$ yaitu:

$\mathrm{E}_{0}$ : Tanpa pemberian ekstrak daun tanaman

$\mathrm{E}_{1}$ : Ekstrak daun Sambiloto

$\mathrm{E}_{2}$ : Ekstrak daun Salam

$\mathrm{E}_{3}$ : Ekstrak daun Kemangi

$\mathrm{E}_{4}$ : Ekstrak daun Jambu Biji

Data daya hambat, insidensi masingmasing jamur patogen pada benih kacang 
tanah, daya kecambah dan tinggi bibit dianalisis dengan sidik ragam dan untuk membandingan rata-rata antar perlakuan dilakukan uji lanjut beda nyata jujur (BNJ) pada taraf $5 \%$.

\section{Pelaksanaan Penelitian \\ Persiapan Benih}

Benih kacang tanah yang digunakan adalah varietas Talam 1 dari BALITKABI Malang dalam bentuk polong sebanyak $4 \mathrm{~kg}$. Total benih yang dibutuhkan dalam penelitian ini adalah sebanyak 3100 benih, dimana 100 benih digunakan untuk isolasi dan identifikasi jamur tular benih, sedangkan 3000 benih digunakan untuk uji aplikasi beberapa ekstrak daun tanaman pada benih kacang tanah.

\section{Isolasi Jamur Patogen pada Benih Kacang Tanah}

Isolasi jamur patogen pada benih kacang tanah dilakukan dengan metode penanaman benih pada medium PDA steril, dalam cawan petri yang dilakukan di dalam laminar air flow cabinet.

\section{Identifikasi Jamur Patogen pada Benih Kacang Tanah}

Identifikasi jamur patogen pada benih dilakukan secara makroskopis dan mikroskopis. Secara makroskopis pengamatan dilakukan dengan melihat warna koloni, arah pertumbuhan dari koloni jamur patogen (ke atas atau ke samping) dan tekstur koloni jamur kasar atau halus.

Identifikasi secara mikroskopis dilakukan terhadap isolat jamur mulai umur 7 hari sampai 21 hari setelah inkubasi pada medium PDA dengan menggunakan mikroskop yaitu dengan melihat warna hifa jamur, memiliki sekat atau tidak serta melihat bentuk spora jamur.

\section{Pembuatan Ekstrak Tanaman}

Daun yang dipilih adalah daun yang tidak terlalu tua, yang berwarna hijau pekat. Masing-masing daun tanaman (sambiloto, kemangi, salam dan jambu biji) sebanyak 100 $\mathrm{g}$ dicuci dengan air mengalir lalu dikeringanginkan hingga permukaan daun tidak lagi basah. Daun tanaman dipotong-potong dengan ukuran sekitar $2 \mathrm{~cm}$ x $2 \mathrm{~cm}$, lalu ditambah 100 $\mathrm{ml}$ aquades steril dan dihaluskan dengan blender sehingga diperoleh konsentrasi $100 \%$. Ekstrak kasar ini disaring dengan menggunakan dua lapis kain kasa dan kemudian dimasukkan dalam erlenmeyer lalu ditutup dengan alumunium foil. Ekstrak masing-masing daun tanaman disimpan dalam lemari pendingin sebagai larutan stok sebelum digunakan untuk penelitian.

\section{Pembuatan Konsentrasi Perlakuan Ekstrak Tanaman}

Ekstrak tanaman (sambiloto, kemangi, salam dan jambu biji) disiapkan sesuai dengan konsentrasi masing-masing perlakuan yaitu sebanyak $30 \mathrm{ml}$. Konsentrasi ekstrak tanaman dibuat dengan mencampurkan larutan stok yang telah disiapkan sesuai perlakuan dengan aquades steril hingga volumenya mencapai 100 $\mathrm{ml}$, masing-masingnya $30 \mathrm{ml}$ larutan stok ditambahkan $70 \mathrm{ml}$ aquades. Setiap perlakuan ditambahkan 0,05 ml Agristick sebagai bahan perekat (Nugraha, 2014). Larutan tersebut kemudian diaduk dengan batang pengaduk agar tercampur rata. Larutan tersebut selanjutnya siap untuk diaplikasikan sebagai perlakuan.

\section{Uji Daya Hambat Beberapa Ekstrak Daun} Tanaman secara In-vitro terhadap Pertumbuhan Jamur Tular Benih Kacang Tanah

Ekstrak masing-masing tanaman sesuai perlakuan sebanyak $50 \mathrm{ml}$ dimasukkan kedalam erlenmeyer yang berisi $450 \mathrm{ml}$ media PDA cair steril hangat, lalu diaduk dengan batang pengaduk hingga merata. Media yang telah dicampur kemudian dituang ke dalam cawan petri sebanyak $20 \mathrm{ml}$ dan medium didiamkan hingga dingin dan padat.

Inokulasi jamur dilakukan di dalam laminar air flow cabinet dengan menumbuhkan masing-masing isolat murni dari jamur patogen pada benih yang diambil dengan cork borer steril berdiameter $5 \mathrm{~mm}$, pada bagian tengah medium PDA yang telah diberi perlakuan ekstrak tanaman. Pertumbuhan koloni jamur diamati setiap hari hingga koloni jamur pada cawan petri tanpa perlakuan $\left(\mathrm{E}_{0}\right)$ telah memenuhi cawan petri.

\section{Uji Ekstrak Beberapa Daun Tanaman pada Benih Kacang Tanah}

Jumlah benih yang dibutuhkan pada pengujian ini adalah 3000 butir benih, 1000 benih digunakan untuk uji pada medium PDA, 1000 benih digunakan untuk uji pada medium tanah steril dan 1000 benih digunakan untuk uji di kertas stensil, dengan 50 benih untuk setiap ulangan dalam satu perlakuan. Benih kacang tanah yang telah diambil secara acak 
direndam di dalam $100 \mathrm{ml}$ larutan ekstrak tanaman sesuai dengan perlakuan dan ditambah $\quad 0,05 \mathrm{ml}$ Agristick sebagai perekat. Perendaman dilakukan selama 20 menit sedangkan untuk perlakuan tanpa ekstrak tanaman, benih direndam dengan aquades steril dengan lama waktu perendaman yang sama. Benih selanjutnya diambil dengan saringan dan dikering-anginkan hingga permukaan benih tidak lagi basah. Benih yang telah diberi perlakuan dilakukan pengujian pada medium PDA dan medium tanah steril.

\section{Pengujian pada Medium PDA}

Benih kacang tanah yang sudah diberi perlakuan dengan berbagai jenis ekstrak daun tanaman disusun secara teratur pada medium PDA steril dalam cawan petri masing-masing sebanyak 5 butir per cawan petri dan diinkubasi selama 7 hari pada suhu kamar dalam inkubator. Masing-masing unit perlakuan terdiri dari 10 cawan petri. Pengamatan dan perhitungan persentase infeksi jamur patogen pada benih kacang tanah dilakukan mulai dari hari kedua setelah inkubasi.

\section{Pengujian pada Medium Kertas Stensil}

Pengujian ini dilakukan dengan mengecambahkan benih kacang tanah yang telah diberi perlakuan pada medium kertas stensil steril dalam baki perkecambahan. Kertas yang digunakan adalah kertas stensil yang sudah disterilkan didalam oven pada suhu $80^{\circ} \mathrm{C}$ selama 2 jam. Sebanyak tiga lembar kertas stensil direndam di dalam aquades steril hingga lembab dan dua lembar diantaranya dibentangkan pada permukaan yang datar. Sebanyak 50 butir benih kacang tanah yang telah diberi perlakuan disusun pada kertas stensil tersebut lalu ditutup dengan satu helai kertas stensil lainnya. Kertas stensil selanjutnya digulung dan diletakan pada baki perkecambahan. Baki perkecambahan yang telah berisi benih dimasukkan kedalam germinator datar dan diinkubasi selama 15 hari. Pengamatan terhadap kecambah normal dan perhitungan persentase daya kecambah benih dilakukan setiap 2 hari sekali mulai hari ke 3 hingga hari ke 15 setelah benih dikecambahkan.

\section{Pengujian pada Medium Tanah}

Pengujian ini dilakukan dengan mengecambahkan benih kacang tanah pada medium tanah dalam seed-bed. Tanah yang digunakan untuk pengujian ini adalah tanah lapisan atas (topsoil) dari lahan UPT Kebun Percobaan Fakultas Pertanian. Tanah diambil pada kedalaman $\pm 20 \mathrm{~cm}$ secara komposit, lalu dibersihkan dari sisa-sisa tanaman. Tanah diayak dan dimasukkan ke dalam kantong plastik, lalu disterilkan dalam dandang selama 1 jam pada suhu $\pm 100{ }^{\circ} \mathrm{C}$ dan diulang 3 kali dengan interval waktu 24 jam. Tanah dibiarkan dingin selama 1 minggu. Tanah dimasukkan ke dalam bak persemaian seberat $8 \mathrm{~kg}$ dan ditambahkan air hingga keadaan macakmacak. Benih ditanam sebanyak 50 butir per seed-bed secara teratur dengan kedalaman \pm 1 $\mathrm{cm}$ dan disiram pagi dan sore hari. Pengamatan dilakukan pada minggu ke-4 setelah benih ditanam.

\section{Pengamatan}

Insidensi Masing-masing Jamur Patogen pada Benih Kacang Tanah setelah diberi Ekstrak Daun Tanaman (\%)

Pengamatan insidensi jamur pada benih kacang tanah pada masing-masing perlakuan dilakukan setelah diinkubasi selama 2-5 hari. Persentase infeksi dihitung dengan rumus berikut:

$$
\text { Insidensi jamur }=\frac{a}{b} \times 100 \%
$$

Keterangan :

$\mathrm{a}=$ Jumlah benih yang terinfeksi masingmasing jamur patogen $\mathrm{b}=$ Jumlah benih yang ditanam

Daya Hambat Beberapa Ekstrak Daun Tanaman terhadap Masing-masing Jamur yang Diisolasi dari Benih Kacang Tanah (\%)

Daya hambat ekstrak daun tanaman terhadap pertumbuhan jamur yang diisolasi dari benih kacang tanah dihitung berdasarkan hasil pengukuran diameter koloni jamur tersebut. Pengukuran diameter koloni jamur dilakukan pada saat koloni jamur pada perlakuan tanpa ekstrak $\left(\mathrm{E}_{0}\right)$ telah memenuhi cawan petri. Berdasarkan rumus:

Keterangan:

$$
\mathrm{D}=\frac{\mathrm{d}_{1}+\mathrm{d}_{2}}{2}
$$

$$
\begin{array}{rlr}
\mathrm{D}= & \begin{array}{l}
\text { Diameter jamur patogen } \\
\text { ditumbuhkan pada medium PDA }
\end{array} \\
\mathrm{d}_{1}= & \begin{array}{l}
\text { Diameter vertikal koloni } \\
\text { ditumbuhkan pada medium PDA }
\end{array} & \text { jamur }
\end{array}
$$


$\mathrm{d}_{2}=$ Diameter horizontal koloni jamur ditumbuhkan pada medium PDA

Hasil penghitungan dari diameter masing-masing koloni jamur, selanjutnya digunakan untuk menghitung persentase daya hambat ekstrak daun tanaman dengan rumus (Noveriza dan Miftakhurohmah, 2010):

Keterangan :

$$
\mathrm{D}=\frac{\mathrm{D}_{1}-\mathrm{D}_{2}}{\mathrm{D}_{1}} \times 100 \%
$$

$\mathrm{D}=$ Daya hambat $(\%)$

$\mathrm{D}_{1}=$ Diameter koloni jamur pada medium PDA tanpa ekstrak tanaman (mm)

$\mathrm{D}_{2}=$ Diameter koloni jamur pada medium PDA dengan ekstrak tanaman (mm)

\section{Daya Kecambah Benih Kacang Tanah (\%)}

Daya kecambah dihitung pada hari ke-6 setelah benih diinkubasi pada media PDA dengan menjumlahkan benih yang telah berkecambah normal untuk masing-masing perlakuan. Daya kecambah benih dapat dihitung dengan rumus:

$$
\text { Daya kecambah }=\frac{n}{N} \times 100 \%
$$

Keterangan:

$\mathrm{n}=$ jumlah benih berkecambah normal

$\mathrm{N}=$ jumlah benih yang dikecambahkan

\section{HASIL DAN PEMBAHASAN}

\section{Insidensi Masing-masing Jamur Patogen pada Benih Kacang Tanah setelah Diberi Beberapa Ekstrak Daun Tanaman (\%)}

Pemberian beberapa ekstrak daun tanaman memberikan pengaruh nyata terhadap insidensi jamur patogen tular benih kacang tanah setelah dilakukan analisis ragam. Data hasil analisis dapat dilihat pada Tabel 1.

Tabel 1. Insidensi Jamur Patogen pada Benih Kacang Tanah Setelah Diberi Perlakuan Ekstrak Daun Tanaman $(\%)$.

\begin{tabular}{lccccc}
\hline \multirow{2}{*}{ Ekstrak daun } & \multicolumn{5}{c}{ Insidensi masing-masing jamur (\%) } \\
\cline { 2 - 6 } & RH & MA & RZ & AS1 & AS2 \\
\hline Tanpa ekstrak (E0) & $26,00 \mathrm{a}$ & $16,00 \mathrm{a}$ & $19,00 \mathrm{a}$ & $11,50 \mathrm{a}$ & $17,50 \mathrm{a}$ \\
Sambiloto (E1) & $15,00 \mathrm{~b}$ & $15,00 \mathrm{a}$ & $11,50 \mathrm{ab}$ & $9,00 \mathrm{ab}$ & $14,00 \mathrm{ab}$ \\
Salam (E2) & $12,00 \mathrm{c}$ & $10,50 \mathrm{ab}$ & $8,00 \mathrm{~b}$ & $6,50 \mathrm{ab}$ & $11,50 \mathrm{bc}$ \\
Kemangi (E3) & $7,50 \mathrm{c}$ & $6,50 \mathrm{~b}$ & $5,50 \mathrm{~b}$ & $5,50 \mathrm{~b}$ & $7,50 \mathrm{c}$ \\
Jambu biji (E4) & $12,50 \mathrm{bc}$ & $8,50 \mathrm{~b}$ & $11,50 \mathrm{ab}$ & $8,00 \mathrm{ab}$ & $11,00 \mathrm{bc}$ \\
\hline
\end{tabular}

Angka-angka yang diikuti oleh huruf kecil yang sama adalah berbeda tidak nyata menurut uji BNJ pada taraf 5\% setelah data ditransformasi $\sqrt{y}$

Keterangan: $\mathrm{RH}=$ Rhizoctonia sp., $\mathrm{MA}=$ Macrophomina sp., $\mathrm{RZ}=$ Rhizopus sp., $\mathrm{AS} 1=$ Aspergillus sp. (1), $\mathrm{AS} 2=$ Aspergillus sp. (2)

Tabel 1 menunjukkan bahwa perlakuan ekstrak daun kemangi secara keseluruhan menunjukkan insidensi yang cenderung lebih kecil dan lebih baik. Hal ini juga didukung oleh kemampuan daya hambat ekstrak daun kemangi terhadap masing-masing jamur patogen yang lebih rendah (Tabel 3). Kemampuan ekstrak tanaman yang berbeda dalam menurunkan infeksi jamur tular benih kacang tanah disebabkan karena kandungan bahan aktif dari keempat ekstrak tersebut berbeda. Kandungan senyawa aktif dalam daun tanaman yang berperan sebagai antifungi flavonoid, saponin, fenol dan minyak atsiri. Sabrina et al. (2014) menyatakan bahwa minyak atsiri berupa methyl chavicol dan linalool yang terdapat dalam kemangi bersifat antifungi, dimana senyawa aktif tersebut tidak ditemukan pada ekstrak daun lainnya sehingga menunjukkan insidensi yang cenderung lebih kecil.
Daya Hambat Ekstrak Daun Tanaman terhadap Masing-masing Jamur yang Diisolasi dari Benih Kacang Tanah Secara In-vitro (\%)

Pemberian beberapa jenis ekstrak daun tanaman memberikan pengaruh nyata terhadap daya hambat pertumbuhan koloni jamur patogen tular benih kacang tanah setelah dilakukan analisis ragam. Data hasil analisis dapat dilihat pada Tabel 2.

Tabel 2 menunjukkan bahwa pada perlakuan tanpa ekstrak daun tanaman tidak terjadi penghambatan terhadap pertumbuhan koloni jamur patogen. Hal ini disebabkan karena pada perlakuan tanpa ekstrak tanaman tidak terdapat kandungan senyawa antifungal, sehingga tidak ada yang berperan sebagai penghambat pertumbuhan koloni jamur patogen. 
Tabel 2. Daya Hambat Ekstrak Daun Tanaman terhadap Pertumbuhan Jamur yang Diisolasi dari Benih Kacang Tanah secara In-vitro (\%) (3 - 7 HSI).

\begin{tabular}{lrrrrr}
\hline \multirow{2}{*}{ Ekstrak Daun } & \multicolumn{5}{c}{ Daya Hambat terhadap Jamur (\%) } \\
\cline { 2 - 6 } & \multicolumn{1}{c}{ RH } & \multicolumn{1}{c}{ MA } & \multicolumn{1}{c}{ RZ } & \multicolumn{1}{c}{ AS1 } & \multicolumn{1}{c}{ AS2 } \\
\hline Tanpa ekstrak (E0) & $0,00 \mathrm{~d}$ & $0,00 \mathrm{c}$ & $0,00 \mathrm{c}$ & $0,00 \mathrm{c}$ & $0,00 \mathrm{e}$ \\
Sambiloto (E1) & $24,00 \mathrm{~b}$ & $28,50 \mathrm{~b}$ & $20,00 \mathrm{a}$ & $9,00 \mathrm{~b}, 00 \mathrm{~b}$ \\
Salam (E2) & $16,00 \mathrm{c}$ & $31,25 \mathrm{~b}$ & $10,00 \mathrm{~b}$ & $9,25 \mathrm{~b}$ & $31,25 \mathrm{a}$ \\
Kemangi (E3 & $30,25 \mathrm{a}$ & $41,00 \mathrm{a}$ & $20,25 \mathrm{a}$ & $15,00 \mathrm{a}$ & $13,25 \mathrm{c}$ \\
Jambu biji (E4) & $29,75 \mathrm{a}$ & $29,25 \mathrm{~b}$ & $8,25 \mathrm{~b}$ & $12,75 \mathrm{a}$ & $10,25 \mathrm{~d}$ \\
\hline
\end{tabular}

Angka-angka yang dikuti oleh huruf kecil yang sama adalah berbeda tidak nyata menurut hasil uji BNJ pada taraf 5\% setelah data ditransformasi $\sqrt{y+0,5}$

Keterangan: RH= Rhizoctonia sp., MA= Macrophomina sp., RZ= Rhizopus sp., AS1= Aspergillus sp. (1), AS2= Aspergillus sp. (2).

Perlakuan ekstrak daun kemangi secara keseluruhan memberikan daya hambat yang berbeda nyata dan lebih baik yaitu $30,25 \%$, $41,00 \%, 20,25 \%$ dan $15,00 \%$ terhadap koloni jamur Rhizoctonia sp., Macrophomina sp., Rhizopus sp. dan Aspergillus sp. (1), dibandingkan dengan perlakuan ekstrak lainnya. Hal ini dapat pula dihubungkan dengan insidensi masing-masing jamur tular benih kacang tanah pada perlakuan ekstrak daun kemangi yang cenderung lebih rendah (Tabel 2). Oyedemi et al. (2008) menyatakan bahwa kandungan senyawa aktif yang terdapat pada kemangi terutama eugenol bersifat antimikroba yang dapat mengganggu fungsi membran sel, menginaktivasi enzim, menghambat sintesis kitin, sintesis asam nukleat dan protein serta menghambat produksi energi oleh ATP (adenosin triphosphat) sehingga pertumbuhan jamur menjadi terhambat.

Tabel 2 juga memperlihatkan bahwa daya hambat ekstrak daun salam berbeda nyata dan lebih baik dibandingkan dengan perlakuan ekstrak lainnya terhadap jamur Aspergillus sp.(2), yaitu sebesar $31,25 \%$. Jamur Aspergillus sp. menghasilkan spora untuk perkembang-biakannya. Diduga bahwa senyawa antimikroba pada daun salam memiliki kemampuan yang lebih baik dalam menggagalkan sporulasi spora jamur sehingga daya hambat yang dihasilkan lebih baik. Penelitian Noveriza dan Miftakhurohmah (2010) menyatakan bahwa ekstrak metanol daun salam pada konsentrasi 5\% mampu menekan pertumbuhan $F$. oxysporum pada tanaman panili dan memiliki daya hambat sebesar 57,16\%. Jamur F. Oxysporum tergolong ke dalam jamur kontaminan yang dapat terbawa benih.
Daya hambat ekstrak daun tanaman terhadap diameter koloni jamur patogen benih kacang tanah pada medium PDA memiliki ukuran yang berbeda-beda dan cenderung memperlihatkan daya hambat yang besar dengan pemberian ekstrak yang berbeda. Perbedaan ini diduga dipengaruhi oleh senyawa anti jamur dari beberapa ekstrak tanaman yang dicampurkan ke dalam media tumbuh jamur (PDA) yang selanjutnya akan terserap oleh hifa jamur dan selanjutnya mengganggu proses metabolisme sel sehingga menghambat pertumbuhan koloni jamur tular benih. Ardiansyah (2000) cit. Asrori (2008), menyatakan bahwa zat anti mikroba dapat menginaktivasi fungsi material genetik, yaitu dengan cara mengganggu pembentukan asam nukleat (RNA dan DNA), sehingga menyebabkan terganggunya transfer informasi genetik yang selanjutnya akan menginaktivasi atau merusak materi genetik yang akibatnya adalah terganggunya proses pembelahan sel jamur atau perkembangbiakan selnya.

Daya Kecambah Benih Kacang Tanah dan
Jumlah Bibit Tumbuh Normal setelah
Benih Diberi Aplikasi Beberapa Ekstrak
Daun Tanaman(\%)
Pemberian beberapa ekstrak daun tanaman memberikan pengaruh nyata terhadap rerata persentase daya kecambah benih kacang tanah dan berpengaruh tidak nyata terhadap jumlah bibit tumbuh normal. Data hasil analisis dapat dilihat pada Tabel 3 .

Tabel 3 menunjukkan bahwa daya kecambah benih kacang tanah yang tidak diberi ekstrak daun tanaman berbeda nyata dengan perlakuan ekstrak daun salam dengan rerata persentase perkecambahannya yaitu $93,00 \%$. Pemberian ekstrak daun sambiloto, kemangi dan jambu biji berbeda tidak nyata sesamanya terhadap daya kecambah benih 
kacang tanah, tetapi cenderung lebih baik dibandingkan dengan tanpa pemberian ekstrak daun tanaman. Hal ini diduga karena benih kacang tanah tanah yang digunakan adalah benih varietas Talam I yang memiliki daya kecambah yang baik, tampak pada daya kecambah benih tanpa pemberian ekstrak daun tanaman maupun dengan pemberian beberapa ekstrak daun tanaman menunjukkan daya kecambah yang tinggi berkisar antara 83,50\% 93,00\%. Hal ini sesuai dengan kriteria benih kacang tanah yang baik berdasarkan peraturan Menteri Pertanian nomor 55/Permentan/SR.120/12/2009 yang menjelaskan bahwa standar mutu benih untuk benih kacang tanah dengan daya kecambah yang tinggi adalah $>80 \%$.

Tabel 3. Daya Kecambah Benih Kacang Tanah dan Jumlah Bibit Tumbuh Normal setelah Benih Diberi Aplikasi Beberapa Ekstrak Daun Tanaman (\%).

\begin{tabular}{lcc}
\hline \multicolumn{1}{c}{ Ekstrak daun } & $\begin{array}{c}\text { Daya kecambah } \\
\text { benih }(\%)\end{array}$ & Jumlah bibit tumbuh normal (\%) \\
\hline Tanpa ekstrak (E0) & $83,50 \mathrm{~b}$ & $96,00 \mathrm{a}$ \\
Sambiloto (E1) & $89,00 \mathrm{ab}$ & $96,50 \mathrm{a}$ \\
Salam (E2) & $93,00 \mathrm{a}$ & $98,00 \mathrm{a}$ \\
Kemangi (E3) & $88,50 \mathrm{ab}$ & $97,50 \mathrm{a}$ \\
Jambu biji (E4) & $86,00 \mathrm{ab}$ & $97,50 \mathrm{a}$ \\
\hline \multicolumn{2}{l}{ Angka-angka yang diikuti oleh huruf kecil yang sama adalah berbeda tidak nyata menurut uji BNJ pada taraf 5\%. }
\end{tabular}

\section{Tinggi Bibit Kacang Tanah pada Media Tanah}

Pemberian beberapa ekstrak daun tanaman pada benih kacang tanah memberikan pengaruh tidak nyata terhadap tinggi bibit kacang tanah. Data hasil analisis dapat dilihat pada Tabel 4.

Tabel 4. Tinggi Bibit Kacang Tanah pada Media Tanah yang Telah Diaplikasikan Beberapa Ekstrak Tanaman pada Umur 30 Hari Setelah Tanam.

\begin{tabular}{lc}
\hline \multicolumn{1}{c}{ Ekstrak Daun } & Tinggi Bibit (cm) \\
\hline Tanpa ekstrak (E0) & $38.85 \mathrm{a}$ \\
Sambiloto (E1) & $36.50 \mathrm{a}$ \\
Salam (E2) & $38.36 \mathrm{a}$ \\
Kemangi (E3) & $36.92 \mathrm{a}$ \\
Jambu biji (E4) & $39,05 \mathrm{a}$ \\
\hline Angka-angka yang diikuti oleh huruf kecil yang sama adalah berbeda tidak nyata menurut uji BNJ pada taraf 5\%.
\end{tabular}

Angka-angka yang diikuti oleh huruf kecil yang sama adalah berbeda tidak nyata menurut uji BNJ pada taraf $5 \%$.

Tabel 4 menunjukkan bahwa tinggi bibit kacang tanah setelah benih diaplikasi dengan beberapa jenis ekstrak daun tanaman pada media tanah berbeda tidak nyata antar sesamanya.

Tabel 4 menunjukkan tinggi bibit yang diperoleh dari hasil pengamatan kacang tanah selama 30 hari setelah tanam berkisar antara $36,50 \mathrm{~cm}-39,05 \mathrm{~cm}$. Berdasarkan deskripsi benih kacang tanah varietas Talam I tinggi tanaman kacang tanah sekitar $\pm 42 \mathrm{~cm}$. Diduga bahwa bibit kacang tanah mengalami gejala etiolasi karena mendapat cahaya matahari yang tidak optimal, hal ini disebabkan letak lokasi penelitian yang berada di pinggir dan wadah semai (seedbed) yang letaknya terlalu rendah serta jarak tanam yang terlalu rapat. Kerapatan tanam merupakan salah satu faktor yang mempegaruhi pertumbuhan tanaman dimana terjadi kompetisi penyerapan cahaya matahari oleh permukaan daun sehingga perkembangan vegetatif tanaman lebih memanjang (Gardner et al., 1991).

\section{KESIMPULAN DAN SARAN}

\section{Kesimpulan}

Dari hasil penelitian pemberian beberapa pestisida nabati untuk mengendalikan jamur tular benih kacang tanah dan pengaruhnya terhadap daya kecambah benih yang telah dilakukan, maka dapat disimpulkan bahwa:

1. Pemberian ekstrak daun kemangi secara keseluruhan menunjukkan insidensi jamur patogen yang cenderung lebih rendah dan lebih baik terhadap jamur Rhizoctonia sp. sebesar 7,50\%, Macrophomina sp. sebesar 6,50\%, Rhizopus sp. sebesar 5,50\%, Aspergillus sp.(1) sebesar 5,50\% dan Aspergillus sp. (2) sebesar 7,50\%. 
2. Pemberian ekstrak daun kemangi secara keseluruhan memberikan daya hambat cenderung lebih baik terhadap jamur Rhizoctonia sp. sebesar 30,25\%, Macrophomina sp. sebesar 41,00\%, Rhizopus sp. sebesar $20,25 \%$ dan Aspergillus sp. (1) sebesar 15,00\%, serta ekstrak daun salam memberikan daya hambat lebih tinggi terhadap jamur Aspergillus sp.(2) sebesar 31,25\%.

3. Pemberian beberapa ekstrak daun tanaman menunjukkan daya kecambah yang baik berkisar antara 83,50\% - 93,00\%. Pemberian ekstrak daun tanaman menghasilkan jumlah bibit tumbuh normal yang cenderung sama.

4. Pemberian beberapa ekstrak daun tanaman tidak memberikan pengaruh terhadap tinggi bibit.

\section{Saran}

Berdasarkan hasil penelitian yang telah dilakukan, Jenis ekstrak yang disarankan sebagai fungisida nabati untuk jamur tular benih kacang tanah adalah daun salam dan kemangi dengan cara perendaman benih. Penelitian lebih lanjut perlu dilakukan untuk mengetahui konsentrasi yang lebih tepat untuk masing-masing ekstrak daun tanaman dalam mengendalikan jamur tular benih kacang tanah. Penelitian lanjutan dengan penggunaan metode ekstraksi yang berbeda dan bahan pelarut yang berbeda.

\section{DAFTAR PUSTAKA}

Asrori, A. 2008. Efektivitas Penghambatan Ekstrak Daging Biji Picung (Pangium edule Reinw) terhadap Pertumbuhan Rhizoctonia sp. secara In-vitro. Skripsi (Tidak Dipublikasikan). Institut Pertanian Bogor, Bogor.

Badan Pusat Statistik Riau. 2019. Riau Dalam Angka 2018. Badan Pusat Statistik Provinsi Riau. Pekanbaru.

Gardner F. P., R. B. Pearce and R. L. Mitchell. 1991. Physiology of Crop Plan. Diterjemahkan oleh H. Susilo. Universitas Indonesia Press, Jakarta.

Noveriza, R. dan Miftakhurohmah. 2010. Efektivitas Ekstrak Metanol Daun Salam (Eugenia polyantha) dan Daun Jeruk Purut (Cytrus histrix) sebagai Anti Jamur pada Pertumbuhan Fusarium oxysporum. Jurnal Littri, 16(1): 6-11.
Nugraha, A. 2014. Uji Beberapa Konsentrasi Tepung Kunyit untuk Mengendalikan Jamur Tular Benih dan Pengaruhnya terhadap Daya Kecambah Benih Jagung. Skripsi (Tidak Dipublikasikan). Universitas Riau, Pekanbaru.

Oyedemi, S. O., A. I. Okoh, L. V. Mabinya, G. Pirochenva and A. J. Afolayan. 2008. The Proposed Mechanism of Bactericidal Action of Eugenol, $\alpha$ Terpinol and $\gamma$-Terpinene Against Listeria monocytogenes, Streptococcus pyogenes, Proteus vulgaris and Escherichia coli. African Journal of Biotechnology, 8(7) : 1280-1286 .

Sabrina, T. I., Sudarno dan H. Suprapto. 2014. Uji Aktivitas Antifungi Perasan Daun Kemangi (Ocimum sanctum Linn.) Terhadap Aspergillus terreus secara In Vitro. Jurnal Ilmiah Perikanan dan Kelautan, 6(2): 176.

Shazia, R. D., Shahnaz dan G. Abdul. 2004. Location of Fungi In Groundnut Seed. University of Karachi, Karachi-75270, Pakistan. Pak.J. Bot., 36(3): 663-668.

Subrahmanyam, P. and M.c. Donald. 1983. Rust Disease of Groundnut. Inform. Bull. No. 13. ICRISAT. 15 pp.

Triharso. 1975. Penelitian Penyakit-penyakit Virus Kacang Tanah. Disertasi Doktor (Tidak Dipublikasikan). Universitas Gadjah Mada, Yogyakarta.

Watanabe, T. 2002. Pictorial Atlas of Soil and Seed Fungi: Morphologies of Cultured Fungi and Key to Species. CRC Press, New York. 